\title{
MsEnod12A Expression Is Linked to Meristematic Activity During Development of Indeterminate and Determinate Nodules and Roots
}

\author{
Petra Bauer, ${ }^{1}$ Simone Poirier, ${ }^{1}$ Pascal Ratet, ${ }^{1}$ Adam Kondorosi $i^{1,2}$ \\ ${ }^{1}$ Institut des Sciences Végétales, CNRS, Avenue de la Terrasse, F-91198 Gif sur Yvette Cedex, France; \\ ${ }^{2}$ Institute of Genetics, Biological Research Center, Hungarian Academy of Sciences, Szeged P.O. Box \\ 521, H-6701 Hungary \\ Received 20 May 1996. Accepted 30 October 1996.
}

During development of nodules and roots, the alfalfa early nodulin gene MsEnod12A is expressed adjacent to the meristem. Using transgenic alfalfa carrying a MsEnod12A promoter-gusA fusion, we investigated the regulation of $M s$ Enod12A expression in mature nodules and roots by GUS assays and reverse transcription-PCR. We found that in alfalfa indeterminate nodules induced by various Fix $^{-}$ Rhizobium meliloti mutants and in spontaneous nodules devoid of rhizobia, MsEnod12A was expressed at the distal end when a persistent meristem was present. However, this gene was not expressed when the meristem was lacking in nodules arrested in development. The MsEnod12AgusA fusion was introduced into Lotus corniculatus plants that form determinate nodules devoid of a persistent meristem. Using these plants we found MsEnod12A-gusA expression only in young nodules and a disappearance in mature nodules. Moreover, when alfalfa roots were treated with auxins a lateral band of MsEnod12A expression was observed surrounding the club-shaped root apex and coinciding with induced lateral meristematic activities. Thus, in all cases MsEnod12A expression was associated with meristematic activities, suggesting that MsEnod12A plays a role in the differentiation processes of nodule and root cells and that it may serve as molecular tool for analyzing meristem establishment during nodule development.

Additional keywords: auxins, early nodulin, Medicago, Lotus, Rhizobium, gusA reporter gene.

Under nitrogen limitation leguminous plants like Medicago and Lotus can interact with their rhizobial partners, resulting in the formation of nitrogen-fixing root nodules. Nodule development begins with the induction of cell divisions in the root cortex. In parallel, rhizobia enter the root via infection of root hairs and migrate in the infection threads towards the cortex where subsequently a nodule primordium is formed. The primordium differentiates into a mature nodule where rhizobia converted into bacteroids start to fix nitrogen.

Corresponding author: A. Kondorosi; E-mail:

Adam.Kondorosi@cactus.isv.cnrs-gif.fr

Present adress of P. Bauer: Dept. of Plant Biology, UC Berkeley, 111, Koshland Hall, Berkeley, CA 94720
Morphological criteria allowed observers to distinguish two major types of nodule differentiation, the indeterminate and determinate nodule types. For development of indeterminate nodules, such as observed on alfalfa and pea, cortical cell divisions are initiated in the inner cortex. A persistent meristem develops at the distal nodule end, generating a gradient of differentiating zones. Adjacent to the meristem continuous invasion of nodule cells is maintained (invasion zone), whereas in the central part nitrogen fixation by bacteroids takes place (nitrogen-fixing zone) and further proximal degradation of plant cells and rhizobia (senescence zone) (for reviews Franssen et al. 1992; Hirsch 1992). In contrast, legumes, such as Lotus and soybean, form determinate nodules that are initiated in the hypodermal cortical cell layer of the root. During nodule differentiation meristematic zones are established only temporarily. Once cell divisions cease, determinate nodules grow only by cell enlargement whereby the central part of the nodules contain big invaded and small uninvaded cells (Franssen et al. 1992; Hirsch 1992).

Signals required for the establishment of a persistent meristem and differentiation of nodule cells are poorly understood. Variations in nodule development have been found with Rhizobium mutants that cause arresting at various stages of nodulation. Rhizobium genetics has allowed the identfication of diffusible lipo-chitooligosaccharides as bacterial signals required for nodule induction, the Nod factors (for review Schultze et al. 1994). Certain bacterial outer surface polysaccharides have been proposed to act in nodule invasion (for review Leigh and Walker 1994). Bacterial signals which might trigger later steps in nodule differentiation, such as leghemoglobin gene induction, have not been reported, although few bacterial genes have been described to be implicated in this process (for example Glazebrook et al. 1993). Moreover, several steps in the differentiation of nodule cells seem to be, at least partially, induced by yet unknown internal plant signals. The decision whether a determinate or indeterminate nodule is formed is controlled by the plant partner and is not influenced by the rhizobia. Plants of a given legume species always develop the same type of nodule. Certain broad-host range Rhizobium strains induce both types of nodules depending on the host plant (Hirsch et al. 1992, and references therein). In alfalfa, even nodules developing spontaneously in the absence of rhizobia are of the indeterminate type harboring an apical meristem (Truchet et al. 1989). 
The characterization of plant early nodulin (Enod) genes has been found to be useful for studying signals controlling nodule development (Nap and Bisseling 1990). Until now, all Enod genes have been identified by differential screening of nodule cDNA libraries or homology-based cloning (for review Schultze et al. 1994). One of them, Enod12, encodes a proline-rich putative structural cell wall protein. Enod12 has been used as molecular marker for establishing a link between different types of nodules (Pichon et al. 1994; Scheres et al. 1992), for investigating Nod factor structure-function relationships (Bauer et al. 1994; Horvath et al. 1993; Journet et al. 1994) and for analyzing the involvement of plant hormones in nodulation (Bauer et al. 1996). However, the possible role of Enod12 in nodule organogenesis and/or the invasion process remains rather obscure. Its expression pattern was related to infection thread growth in root and nodule cells of pea and Medicago, and it was originally hypothesized that it might be a component of infection threads (Scheres et al. 1990; Govers et al. 1991; Pichon et al. 1992; Bauer et al. 1994). Recently, it was demonstrated that in vetch Enod12 was not likely to be involved in root hair deformation (Vijn et al. 1995a). Enod12 mutants have been found in alfalfa. These plants, devoid of any Enod 12 sequences, were still capable of forming nitrogenfixing nodules, indicating that Enod12 genes were not essential for nodule development or that their function could be substituted by related genes (Csanadi et al. 1994).

Earlier, we identified two Enodl2 homologs of the tetraploid Medicago sativa, MsEnod12A, and MsEnod12B, whose expression was studied by reverse transcription-PCR. We found that these two genes were differentially expressed during nodule development (Allison et al. 1993; Bauer et al. 1994). Expression of MsEnod12B in the root was activated within a few hours after addition of purified Nod factors to the root, similar to that of the Enod12 genes from pea, vetch, and from the diploid M. truncatula which were induced in the root epidermis and in root hairs (Bauer et al. 1994; Horvath et al. 1993; Journet et al. 1994). In contrast, expression of MsEnod12A was only detected once small nodules were visible (Bauer et al. 1994). Despite the differential Enod12 induction during the very early nodulation phase, all Enod12 genes characterized were expressed in the early invasion zone of the mature nodule (Bauer et al. 1994; Pichon et al. 1992; Scheres et al. 1992; Vijn et al. 1995b). A low level of MsEnod12A expression was detected in empty and spontaneous nodules which has led us to hypothesize that it might be associated with nodule invasion. A drawback of these experiments was, however, that we could not localize gene expression in individual nodules. To overcome this, we constructed transgenic alfalfa carrying a MsEnod $12 A$ promoter-gusA reporter gene fusion. We found that MsEnod12A induction starting in small cortical cell division foci did not require the presence of rhizobia or Nod factors, and the gene was also expressed in lateral root primordia and in front of the root tips (Bauer et al. 1996).

In this work, the regulation and possible role of MsEnod $12 \mathrm{~A}$ during the differentiation of nodules and roots have been studied by using the transgenic alfalfa plants carrying the MsEnod12A-gusA fusion. In addition, we introduced the MsEnod12A-gusA fusion into L. corniculatus which allowed us to compare the MsEnod $12 A$ expression patterns during development of various forms of indeterminate alfalfa nodules and of determinate Lotus nodules. Moreover, we studied MsEnod12A expression in front of the root tips after auxin treatments. In all these cases, we found a correlation between MsEnod $12 A$ expression and meristematic activities, suggesting that Enod12 expression might be associated with cell differentiation.

\section{RESULTS}

\section{MsEnod12A is expressed at the distal end of nodules containing a persistent meristem.}

Previously we described the construction of transgenic $M$. sativa ssp. varia A2 plants carrying a MsEnod12A-gusA fusion and the use of these plants for studying nodule initiation. The measured GUS activities were confirmed by in situ hybridization and by reverse transcription-PCR, thus this fusion represented a reliable marker for following the activation of the endogenous MsEnod12A gene (Bauer et al. 1996). In mature effective nodules induced by $R$. meliloti strain AK631 $M s$ Enod $12 A$ was expressed at the apical end (Fig. 1A). To get insight into the regulation of MsEnod $12 A$ in the mature nodule the spatial expression of MsEnod12A was investigated in individual ineffective nodules blocked at various developmental stages.

First, the possible involvement of metabolic or bacteroidderived signals in the regulation of MsEnod12A was tested. Transgenic roots containing the MsEnod12A-gusA fusion were inoculated with a nifH R. meliloti mutant (AK1282) defective in the enzyme nitrogenase (Forrai et al. 1983; Putnoky et al. $1988)$ and with a bacA $R$. meliloti mutant (Rm8368) blocked in bacteroid differentiation (Glazebrook et al. 1993), respec-

Fig.1. MsEnod12A expression in nodules induced by wild type Rhizobium meliloti and various Fix ${ }^{-}$mutants and in spontaneous nodules of transgenic alfalfa carrying the MsEnod12A-gusA fusion. (A) 10- $\mu \mathrm{m}$ section of a 20-day-old nodule induced by wild type R. meliloti strain AK631 and stained with X-Gluc only (blue staining). (B-D) Nodules induced by Bac ${ }^{-}$strain Rm8368 carrying a constitutive lacZ fusion. (B) $10-\mu \mathrm{m}$ section of a mature nodule of 3 weeks. In addition to the Gus staining, the section was stained for starch (violet black staining, arrowhead) with iodine. (C) $100-\mu \mathrm{m}$ section stained with X-D-gal for detecting the bacterial encoded $\beta$-Galactosidase activity (blue) and with iodine for starch (brown staining). The section was not stained for GUS. (D) Magnification of the central part in (C), note few infection threads (if) stained in blue ( $\beta$-galactosidase activity) and starch-containing cells stained in violet black (arrowheads). (E-H) 11-day-old empty nodules induced by $R$. meliloti strain Rm0540 carrying a constitutive lacZ fusion. (E) and (F) Whole root observations showing GUS activity (blue staining) detected in blue, partially localized to parts of the empty nodules (thick arrow) or absence of GUS activity in empty nodules (thin arrow). (G) $10-\mu \mathrm{m}$ section after toluidine blue staining. Note darkly stained cell wall material on the surface indicating a defence response (arrow). No region with darkly violet-stained nuclei was detected suggesting the absence of a meristematic zone. (H) Same as (G) showing faint GUS activity (blue staining) in inner cells (open arrow). Bacteria are restricted to the cell surface (magenta-D-gal, red staining, black arrows). (I-K) Spontaneous nodules after 3 weeks of nitrogen starvation. (I) Whole root observation. Gus activity is revealed by the blue staining. (J) 10- $\mu \mathrm{m}$ section showing GUS activity (blue staining) at the distal end (open arrow) and strong amyloplast deposition in the central part (brown staining, arrow head). (K) Magnification of ( $\mathrm{J})$ after toluidine blue staining revealing the meristematic zone with strongly stained nuclei, indicated by asterisks. Symbols not indicated in the legend: stars $=$ meristematic zone. Horizontal bars $=150 \mu \mathrm{m}$, double bars $=500 \mu \mathrm{m}$. 

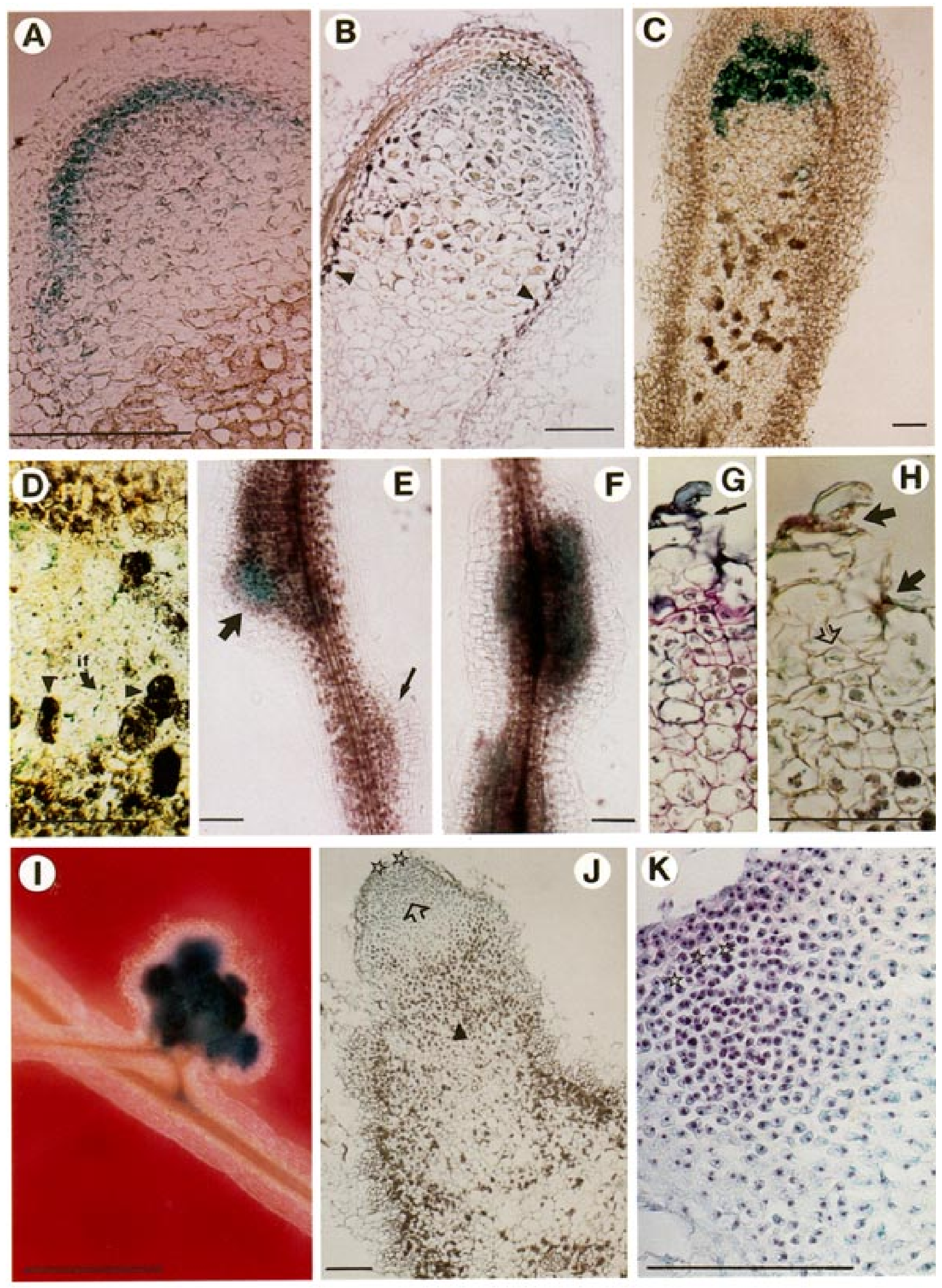
tively. To localize the presence of $\mathrm{Rm} 8368$ bacteria in the nodules a constitutively expressing $\delta$-ALA::lacZ fusion (Leong et al. 1985) was introduced into this strain. During the development of nodules induced by nifH mutants and wildtype rhizobia, no differences in GUS staining patterns were found (data not shown, Bauer et al. 1996). During nodule formation elicited by the $\mathrm{Bac}^{-}$mutant, GUS staining was also generally found all over the nodule primordia (data not shown) except in small brownish primordia of nodules arrested in growth, as also observed in nodules induced by the exoY mutant strain Rm0540 (see Fig. 1E). Mature nodules induced by bacA mutants were white due to the lack of leghemoglobin (Fig. 1B-D; see also Glazebrook et al. 1993). The bacteria remained inside the numerous infection threads of the invasion zone (Fig. 1C, blue staining) and in the few infection threads (if) observed in the central zone (Fig. 1D, blue staining). Starch deposition was frequently observed in large cells inside these nodules (Fig. 1D, violet-black staining, indicated by black arrowheads). MsEnod12A expression was found at the distal end of the nodules, as observed for those induced by the wild-type $R$. meliloti (Fig. 1B) indicating that MsEnod12A expression was not influenced in nodules altered in bacteroid differentiation and carbon/nitrogen metabolism.

\section{MsEnod12A-gusA expression is down-regulated in nodules blocked in their development.}

The nodules analyzed in the previous section were fully invaded by wild type and $\mathrm{Bac}^{-}$mutants rhizobia and generally

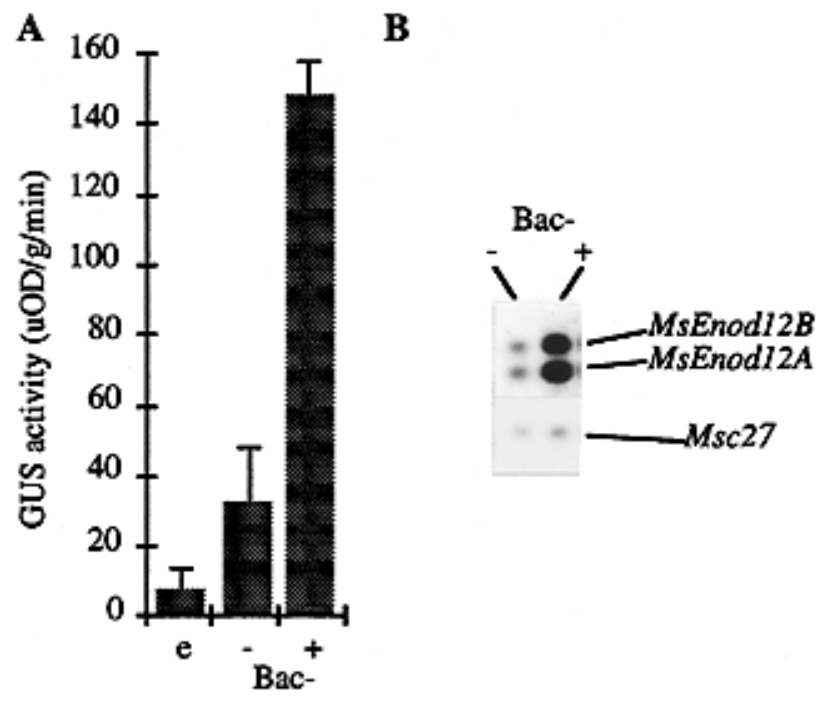

Fig. 2. Analysis of MsEnod12A expression in growth-arrested and growing $\mathrm{Bac}^{-}$nodules and empty nodules induced on the transgenic roots. (A) Spectrocolorimetric analysis of GUS activities performed on total protein extracts prepared from empty nodules (e) induced by Rm0540, small, brownish, growth-arrested $\mathrm{Bac}^{-}$-nodules (-) and white, growing $\mathrm{Bac}^{-}$-nodules (+), both induced by $\mathrm{Rm} 8368$. The measurements and error bars represent the mean changes of OD units per gram per minute and standard deviations out of four measurements. (B) RT-PCR analysis of MsEnod12A and control Msc27 expression. After coamplification during 20 cycles the PCR products were separated on agarose, transferred to a nylon membrane and subsequently hybridized to MsEnod $12 B$ and $M s c 27$ probes. developed into mature nodules harboring a meristematic zone. To test whether Rhizobum invasion and/or continuous nodule development might be required for gene induction, GUS staining patterns were followed in empty nodules elicited by Rm0540 exoY mutants (Müller et al. 1988, 1993). We used a derivative of strain Rm0540 constitutively expressing a $\delta$ ALA::lacZ fusion (Leong et al. 1985) allowing the easy demonstration of the presence of the bacteria (gift from A. Becker, Bielefeld). Rm0540 bacteria are not capable of invading nodules via infection threads and nodules remain free of bacteria during the first 6 weeks (Niehaus et al. 1993). Eleven days after inoculation with strain Rm0540 small empty nodules developed exhibiting varying expression patterns. GUS activities in these nodules were low compared to wild-type nodules so that overnight incubation with the GUS substrate was required (see also Fig. 3 below). GUS activitiy was observed either in the whole nodule (Fig. 1F), in parts of the nodules (Fig. 1E, thick arrow) or was not detectable at all (Fig. 1E, thin arrow). A semithin section through an empty nodule with GUS activity restricted to a part of the nodule showed highly autofluorescent material incorporated into the cell walls of the outer cell layers which stained distinctly with toluidine blue, indicating a defense reaction against exo $R$. meliloti mutants as described by Niehaus et al. (1993) (Fig. 1G, arrow). A meristematic region characterized by small cells darkly stained with toluidine blue was not detectable on any of the sections through seven empty nodules analyzed (Fig. 1G). $\beta$-Gal staining showed that bacteria were present around the cell surface but not inside the cells (Fig. 1H, red staining, arrows). Low GUS activity was localized in cells below the nodule periphery (Fig. 1H, open arrow).

The low MsEnod12A expression in empty nodules might result from the absence of Rhizobium invasion. Empty nodules on alfalfa are induced by $R$. meliloti mutants defective in the production of outer surface exopolysaccharides, including both the exopolysaccharides (EPS) and the capsular polysaccharides (KPS) (for review Leigh and Walker 1994). Low and high molecular weight EPS and KPS therefore represented possible candidates as signal molecules which might be able to trigger MsEnod12A expression. To test this hypothesis, transgenic alfalfa plants were inoculated with different $R$. meliloti outer surface mutants. The wild-type strain Rm41 producing both EPS and KPS was used as a control. The exoB mutant AK631 and strain PP711 carrying a mutation in the fix23 region are Rm41-derived and affected in EPS and KPS production, respectively (Forrai et al. 1983; Kondorosi et al. 1984). Since EPS and KPS can functionally replace each other in the nodule infection process, these mutants nodulate alfalfa like wild type rhizobia, i.e., they are $\mathrm{Fix}^{+}$(Petrovics et al. 1993). Two different $e x o B$ and fix23 double mutants, PP666 and PP618 (derived from Rm41), were used for inducing Fix ${ }^{-}$ empty nodules (Putnoky et al. 1990). No major differences in MsEnod12A GUS staining patterns or intensities were observed between the nodules induced by Rm41, AK631 and PP711, although the bacteria contained different outer surface components (data not shown). The PP666- and PP618-induced empty nodules however exhibited similar GUS staining patterns as those elicited by Rm0540 shown on Figure 1E-H. Analysis of MsEnod12A expression was also performed on RNA level applying RT-PCR. Again, no differences were found in the levels of MsEnod12A transcripts between the 
nodules induced by Rm41, AK631, and PP711, using Msc27 as constitutive control, whereas the PP666- and PP618induced empty nodule samples both showed reduced expression levels (not shown). This result correlates with the reduced level of MsEnod12A expression observed previously in a sample of empty nodules induced by PP553 strain (exoB, fix23 mutant derivative of $\mathrm{Rm} 41$ ) as compared to nodules induced by wild-type rhizobia (Bauer et al. 1994) as well as the reduction of GUS activity measured in Rm0540-induced nodules (see below). In a further experiment $50 \mu \mathrm{g}$ of crude extracts of EPS or KPS (Petrovics et al. 1993) prepared from Rm41 bacteria were applied to transgenic alfalfa roots, but neither GUS induction nor MsEnod12A RT-PCR signals were detected in roots during the first 4 days tested (not shown). These results indicate that the outer surface components of $R$. meliloti are not involved in MsEnod12A regulation.

A further possibility was that the irregular shapes of empty nodules and their early arrest in development were the reason for the low MsEnod12A expression. To verify that the histochemical GUS stainings in growth-arrested nodules did not result from a technical problem we first performed spectrocolorimetric GUS measurements. For this purpose, the following three nodule samples were collected from the transgenic roots and used for total protein extraction: empty nodules induced by Rm0540 (lane e), small brownish, growth-arrested $\mathrm{Bac}^{-}$ nodules (lane -) and white growing $\mathrm{Bac}^{-}$nodules (lane + ), the latter two induced by $\mathrm{Rm} 8368$ and thus elicited by identical bacterial signals. $\mathrm{Bac}^{-}$nodules had the advantage over empty nodules that they were formed in a higher amount on the roots, so that a higher number of growing and growth-arrested nodules could be harvested. Spectrocolorimetric analysis showed that GUS activity was about 15 to 20 times lower in empty nodules and five times lower in growth-arrested $\mathrm{Bac}^{-}$ nodules, both compared to growing $\mathrm{Bac}^{-}$nodules (Fig. 2A).

To exclude that the lower GUS staining in growth-arrested nodules was a technical artefact due to decreased penetration of the GUS substrate into the cells or due to inhibitory effects on the GUS enzymatic reaction because of phenolic secondary metabolites, total RNA was prepared from $\mathrm{Bac}^{-}$nodules and used in an RT-PCR assay to detect expression of the endogenous MsEnod12A gene. Fig. 2B shows that significantly lower level of MsEnod12A expression was detected in the sample of small brownish $\mathrm{Bac}^{-}$nodules (lane -) than in that of growing $\mathrm{Bac}^{-}$nodules (lane + ) despite the fact that the formation of both types of nodules were induced by identical signals. In growing $\mathrm{Bac}^{-}$nodules the level of MsEnod $12 \mathrm{~A}$ expression was equivalent to that in nodules of wild-type rhizobia (not shown), indicating that the level of MsEnod12A transcript accumulation was correlated with the developmental state of the nodules rather than with Rhizobium invasion.

\section{MsEnod12A is expressed at the apical end in spontaneous nodules.}

To further investigate whether continuous nodule growth is required for MsEnod $12 \mathrm{~A}$ expression in the so-called early invasion zone the histochemical GUS staining patterns were followed during the development of spontaneous nodules. After 3 weeks of nitrogen starvation in the absence of bacteria the transgenic $M$. sativa ssp. varia A2 plants developed spontaneous nodules at a low frequency. GUS staining was found in white growing spontaneous nodules (Fig. 1I-K). As shown on a semithin section, MsEnod $12 \mathrm{~A}$ expression started adjacent to the meristem and became strongest in the elongating and differentiating cells of the nodule (Fig. 1J, open arrow, compare to Fig. $1 \mathrm{~K}$ after toluidine blue staining with meristematic area indicated by asterisks). No GUS signals were detected in the differentiated cells of the central starch-accumulating zone (Fig. 1J, black arrowheads). Interestingly, few small brownish spontaneous nodules were observed which did not stain with the GUS substrate similar to some of the empty nodules and small brownish $\mathrm{Bac}^{-}$nodules described above, suggesting again that MsEnod12A expression is independent of $R$. meliloti invasion.

\section{MsEnod12A-gusA expression ceases in mature determinate nodules of $L$. corniculatus.}

To confirm the correlation between MsEnod12A expression and continuous nodule development, we analyzed the GUS staining patterns generated during the development of determinate nodules. For this purpose, the MsEnod12A-gusA fusion was introduced into the tetraploid L. corniculatus via Agrobacterium rhizogenes-mediated transformation. From 15 hairy root clones seven independent transgenic plants were regenerated and five out of the seven plants expressed the gusA fusion during nodule development and contained correct structures of the integrated DNA, as verified by DNA hybridization. Since the presence of the rol oncogenes perturbs and retards events of the early nodulation phase also in Lotus (S. Poirier, P. Ratet, unpublished data) one of the regenerated transgenic plants was brought to flowering and pollinated with a wildtype untransformed plant. Among the $\mathrm{F}_{1}$ progeny two plants were selected which contained nptII and gusA sequences, but were devoid of rol genes (see Materials and Methods). Rooted cuttings of these $\mathrm{F}_{1}$ plants were inoculated with $R$. loti strain NZP2037. Four days later, nodules of different ages were collected and stained histochemically for GUS activity. GUS staining occurred only in white, but not pink Lotus nodules (Fig. 3A-E), however at an apparently lower level in the transgenic plant analyzed than in alfalfa nodules, as determined from the relative incubation times required for visible GUS staining. In very small white nodules GUS staining occurred in all cells of the central part (Fig. 3A) as well as in parenchyma cells and around vascular tissue, albeit at lower level, as observed in alfalfa nodules (Bauer et al. 1996). In bigger white nodules MsEnod12A was expressed in a zone in between the peripheral starch-containing cells (violet-black color due to iodine staining of starch, arrowheads) and cells of the central part (Fig. 3B). Interestingly, in these nodules, toluidine blue staining revealed two zones with darkly stained nuclei. One toluidine blue-stained zone coincided with the area of GUS activity in the central part, the other zone with toluidine blue-stained nuclei surrounded the starch-containing zone and did not or only weakly exhibited GUS staining (Fig. $3 \mathrm{C}$ arrow). No GUS staining was detectable once nodules were pink due to the presence of leghemoglobin (Fig. 3D-E). A starch-contaning zone (Fig. 3D, violet-black color due to iodine staining of starch, arrowhead) and a small zone of cells whose nuclei were stained with toluidine blue were, however, still detectable (Fig. 4E, long arrow).

Thus, MsEnod12A-gusA expression occurred transiently during development of determinate Lotus nodules. 


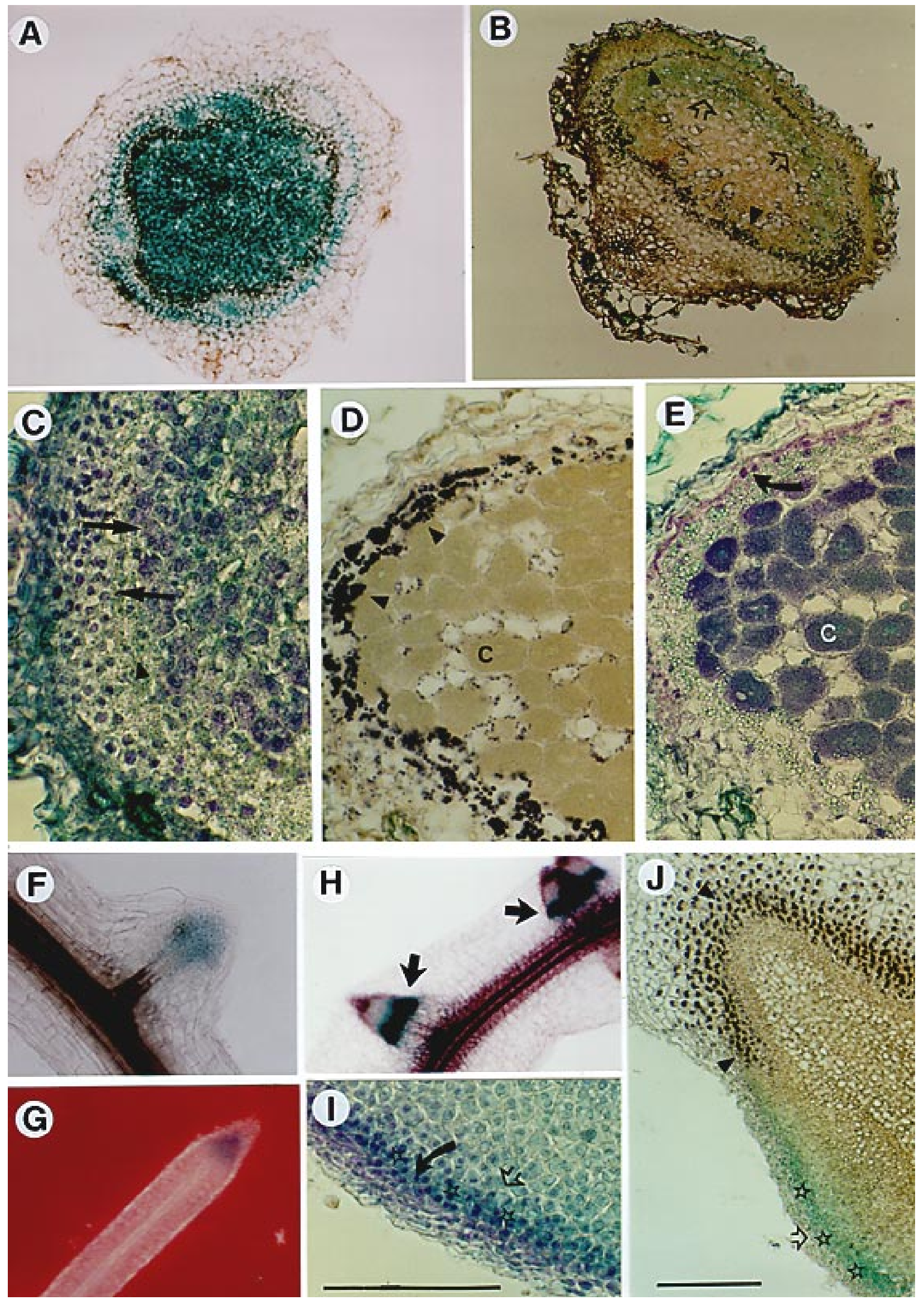




\section{During lateral root development and after auxin treatment MsEnod12A expression is associated with meristematic activity.}

During root and lateral root development MsEnod12A expression was observed in front of the tips of developing principal or lateral roots (Fig. 3F and G). Benzoic acid derivatives with auxin activities applied to legume roots have been described to induce fasciated roots and root tip swellings with lateral meristematic zones near the tips (Allen et al. 1953). To analyze a possible link between MsEnod12A expression and meristematic activity in this tissue, we applied $10 \mu \mathrm{M} 2,4-$ dichlorophenoxyacetic acid $(2,4-\mathrm{D})$ to roots of the transgenic plants for up to 8 days (see Materials and Methods). In addition to lateral root bumps, striking morphological changes were induced by auxin, such as club-shaped root tips and stunting of the roots (data not shown). GUS activity was observed as a thin band in front of the swollen root apices (Fig. $3 \mathrm{H}$, indicated by thick arrows). Similar GUS staining patterns and root tip morphology were found also after application of indole acetic acid and naphtalene acetic acid (not shown). Figure $3 \mathrm{~J}$ shows a semithin section through a root apex excised after 8 days of treatment with 2,4D and stained for GUS activity, similar to the one indicated with a thick arrow in Figure $3 \mathrm{H}$. On the lateral sides at the distal ends, large amounts of starch-containing amyloplasts were detected (Fig. 3J, starch in violet-black after iodine staining, arrowheads). After staining with toluidine blue we observed at the lateral sides of the root tip numerous small cells with big violet nuclei (arrow in Fig. 3I, magnification of the region marked by asterisks on Fig. 3J), suggesting that they were actively dividing. GUS activity was detected on the lateral sides (indicated by an open arrow in Fig. 3I-J): this staining apparently marked the meristematic region induced by auxin in the root apex in agreement with the results described by Allen et al. (1953).

\section{DISCUSSION}

Here we showed that during the formation of indeterminate and determinate nodules and root development the expression of the early nodulin gene MsEnod12A is associated with the presence of a persistent meristem and cell division. Using transgenic Medicago and Lotus containing a MsEnod $12 A$ promoter-gusA fusion, MsEnod12A expression was followed via histochemical GUS stainings in combination with reverse transcription-PCR experiments. This is the first study showing a comparison of the expression patterns of an Enod12 gene during development of indeterminate and determinate nodules.

In indeterminate alfalfa nodules, MsEnod $12 \mathrm{~A}$ expression was localized to a sharp zone next to the meristem at the distal end. Pea and M. truncatula Enod12 genes are expressed in a similar small zone, previously designated by Pichon et al. (1992) as the early invasion zone (see also Scheres et al. 1990). In V. sativa, Enod12 expression takes place in a broader zone extending further into the invasion zone (Vijn et al. 1995). It is intriguing that once a nodule is established, all Enod12 genes including MsEnod12A are expressed at a similar site in mature nodules while MsEnod $12 A$ was differentially expressed with respect to the very early nodulation events and Nod factor induction (Bauer et al. 1994; Horvath et al. 1993; Journet et al. 1994). The fact that the pea Enod12 genes as well as the M. truncatula Enod12 were expressed at the distal end in pseudonodules or spontaneous nodules, both structures devoid of rhizobia and infection threads, suggested that this gene activation might be independent of Nod factor production (Scheres et al. 1992; Pichon et al. 1994). Our previous RT-PCR studies indicated that MsEnod12A expression might be regulated by Rhizobium invasion since in empty nodules it was detectable at a significantly reduced level, and in spontaneous nodules it was absent (Bauer et al. 1994). However, total RNA analysis was limited by the fact that MsEnod $12 \mathrm{~A}$ expression could not be followed in individual nodules induced by the $R$. meliloti mutants. Here we localized the cell-specific $M s$ Enod $12 A$ induction in individual nodules arrested at various stages of development and functioning and in spontaneous nodules. We demonstrated that MsEnod $12 A$ was expressed at the distal end in nodules as long as a persistent meristem was present. On the other hand, MsEnod12A expression was not found in nodules which were blocked in development, and consequently did not harbor an active meristem, p. ex in empty nodules (see also Yang et al. 1992), in small brownish $\mathrm{Bac}^{-}$and small, brownish spontaneous nodules. We think therefore, that the absence of MsEnod12A and MsEnod12B amplification signals seen in former RT-PCR experiments (Bauer et al. 1994) using a sample of 5-week-old spontaneous nodules might have been the result of an arrest in development of the spontaneous nodules after such a long time of nitrogen starvation. On the other hand, from the same 5-week-old spontaneous nodule sample Msc27 and Enod40 sequences were amplified showing that Enod12 expression was specifically down-regulated in these already developed spontanous nodules (Bauer et al. 1994; Crespi et al. 1994). However in contrast to empty nodules induced by $R$. meliloti, spontanous

Fig. 3. MsEnod12A expression during development of determinate Lotus corniculatus nodules and in Medicago sativa roots after 2,4D treatment. (A-E) Histochemical GUS staining of MsEnod12A expression in determinate nodules of different developmental stages induced on the roots of transgenic $L$. corniculatus plants carrying the MsEnod12A-gusA fusion. (A) 100- $\mu \mathrm{m}$ section of a small, white nodule with GUS activity (blue staining) in all central cells. (B) 10- $\mu \mathrm{m}$ section of a white developed nodule with GUS staining (open arrow) restricted to a zone below the starch zone (brown staining, arrowheads). (C) Magnification of the area stained in blue (GUS) in (B) but in addition stained with toluidine, with arrows indicating meristematic regions containing stained nuclei, surrounding the starch-accumulating layer (arrowhead). (D) 10- $\mu \mathrm{m}$ section of a pink (nitrogen fixing) nodule stained for GUS, but devoid of GUS activity and additionally stained with iodine to indicate the starch accumulation zone (violet-black staining, arrowheads). Cells (c) of the central zone of the nodule filled with nitrogen-fixing bacteroids are indicated. (E) Same as (D) after toluidine blue staining showing few darkly stained nuclei (arrow) only outside the starch accumulation zone. (F-J) MsEnod12A expression in M. sativa root tips. (F-G) Whole root observation of a developing lateral root with GUS activity (blue staining) near the root apex. (H-J) Modifications of the root tips after treatment with $10 \mu \mathrm{M} 2,4 \mathrm{D}$. (H) Whole root observation, note root tips with bands of GUS activities indicated by arrows. (I) Magnification of (J) after toluidine blue treatment (violet staining, arrow) outside of the blue GUS staining (open arrow), indicating lateral meristematic regions. (J) 10- $\mu$ m section through a root apex similar to that indicated with a thick arrow in (H) showing lateral GUS activity (open arrow) and iodine staining of starch at the tip (violet-black staining, arrowhead). Symbols: stars $=$ meristematic zone. Horizontal bars $=150 \mu \mathrm{m}$, double bars $=500 \mu \mathrm{m}$. 
nodules appeared randomly at irregular intervals on roots of only a relatively low fraction of nitrogen-starved plants, therefore the kinetics of nodule formation could not be determined, which could have provided support for this hypothesis. Thus, this analysis showed that neither Rhizobium invasion nor later steps in nodule differentiation, nor bacteroid differentiation, nor metabolic changes related to nitrogen fixation control MsEnod12A expression, neither negatively nor positively. We could not find any evidence for direct gene regulation by either bacterial outer surface EPS or KPS in the roots and the nodules. Thus our results together represent correlative evidence that MsEnod12A expression is rather related to the nodule organogenetic process in itself.

A further indication for the association of MsEnod12A expression with meristematic activities was provided by the observation that during development of determinate nodules MsEnod $12 A$ expression took place only temporarily. In young white $L$. corniculatus nodules we found evidence for the existence of differentiating zones. GUS activity was found in cells below cell layers that accumulated starch. However, since starch accumulation occurred peripherally compared to MsEnod12A expression, the zones presumably were not generated by a single meristem, as is the case in indeterminate nodules. Indeed, we observed two meristematic areas on either side of the starch-accumulating zone. Interestingly, Taté et al. (1994) described recently that during the early development of determinate Phaseolus vulgaris nodules different zones might exist. In contrast to young Lotus nodules, we found that in mature Lotus nodules of reddish color due to leghemoglobin, GUS activity was not found any longer in the single central zone containing the big invaded and small noninvaded cells or in the periphery. This is in clear contrast to mature indeterminate nodules where MsEnod $12 \mathrm{~A}$ expression at the distal part persists near the meristem. The MsEnod $12 \mathrm{~A}$ expression patterns during development of determinate nodules thus support the conclusion that the expression of this gene is associated with meristematic activities.

During development of alfalfa roots MsEnod $12 A$ is expressed at the root apex. Treatment with 2,4D and other auxins induced swelling of root tips in alfalfa. At the site of swelling a lateral band of MsEnod12A expression became apparent coinciding with the formation of a lateral meristematic region. Interestingly, several marker genes for the activated cell cycle show a similar band of gene expression at the apex of auxintreated roots, confirming that on the lateral sides of auxintreated root tips cell divisions take place (Ferreira et al. 1994; Hemerly et al. 1992). Therefore, not only in nodules but also in roots the MsEnod12A expression coincided with meristematic activities (see also Allen et al. 1953). We did not observe any gusA expression in front of the tips of Lotus roots. Since MsEnod12A-gusA expression was significantly lower in Lotus than in Medicago nodules, GUS activity in Lotus roots was presumably below the detection level.

Altogether, we presented several independent indications that MsEnod12A expression is linked with cell division and cell differentiation, but not with the presence of infection threads and rhizobia or with metabolic changes. The MsEnod12A-gusA fusion can therefore be used as a marker for submeristematic cells. Based on our results we speculate that MsEnod $12 A$ as a proline-rich protein may play a role in the formation of the cell wall of newly generated and differentiating nodule and root cells. In light of the observations by Scheres et al. (1992) and Pichon et al. (1994) on Enod12 expression in non-invaded nodules we think that this function can also be extended to the other Enod12 genes.

The patterns of MsEnod12A expression are also interesting with respect to the possible evolutionary origin of nodules from modified lateral roots. Enod12 might have evolved from a root-specific gene expressed during cell differentiation processes. Root and nodule development obviously require many identical gene functions which is reflected by the fact that the expression of several early nodulin genes is also detectable in roots (see also Bauer et al. 1994; Crespi et al. 1994). Moreover, several Enod genes were found to be expressed in rootderived structures that resemble nodules and that can be induced by plant growth regulators (for example Hirsch et al. 1989; Scheres et al. 1992; Cooper and Long 1994; Bauer et al. 1996). It is therefore likely that during evolution plants may have recruited similar genes for nodule and root morphogenesis.

\section{MATERIALS AND METHODS}

\section{Generation of transgenic plants.}

The binary vector pPR89 harboring the transcriptional MsEnod $12 \mathrm{~A}$ promoter (3.7 kb)-gusA fusion and a kanamycin selection marker gene (ntII) was used for plant transformation (Bauer et al. 1996).

Table 1. Description of Rhizobium strains utilized

\begin{tabular}{|c|c|c|}
\hline Strain & Relevant characteristics & Reference \\
\hline \multicolumn{3}{|l|}{ R. meliloti } \\
\hline Rm41 & Wild-type, Hungarian isolate & Szeged collection \\
\hline AK631 & $\mathrm{Rm} 41$ exoB, $\mathrm{Nod}^{+}, \mathrm{Inf}^{+}, \mathrm{Fix}^{+}$ & Kondorosi et al. 1984 \\
\hline PP711 & $\begin{array}{l}\text { Rm41, containing a Tn5 insertion in the promoter of ORF9 of the fix } 23 \text { region in } \\
\text { the same position as PP618, } \text { Nod }^{+}, \text {Inf }^{+}, \mathrm{Fix}^{+}, \mathrm{KPS}^{-}\end{array}$ & P. Putnoky (Szeged) \\
\hline AK1282 & AK631 nifH, $\mathrm{Nod}^{+}, \mathrm{Inf}^{+}, \mathrm{Bac}^{+}, \mathrm{Fix}^{-}$ & $\begin{array}{l}\text { Forrai et al. } 1983 ; \\
\text { Putnoky et al. } 1988\end{array}$ \\
\hline $\operatorname{Rm} 8368$ & Rm1021bacA386, $\mathrm{Nod}^{+}, \mathrm{Inf}^{+}, \mathrm{Bac}^{-}, \mathrm{Fix}^{-}$ & Glazebrook et al. (1993) \\
\hline Rm8368 (pXLGD) & M-1996-1206-02R & This work \\
\hline PP618 & $\begin{array}{l}\text { AK631 carrying a } T n 5 \text { insertion in the promoter of ORF9 of the fix } 23 \text { region, } \\
\text { Nod }^{+}, \text {Inf }^{-}, \text {Fix }^{-}, \text {KPS }\end{array}$ & $\begin{array}{l}\text { Putnoky et al. } 1990 \mathrm{E} \text {. } \\
\text { Kiss (Szeged) pers. comm. }\end{array}$ \\
\hline PP666 & $\begin{array}{l}\text { AK631 carrying a } \operatorname{Tn} 5 \text { insertion in ORF1 of the fix } 23 \text { region } \mathrm{Nod}^{+}, \mathrm{Inf}^{-}, \mathrm{Fix}^{-} \text {, } \\
\text { KPS }^{-}\end{array}$ & $\begin{array}{l}\text { Putnoky et al. (1990); Petrovics et al. } \\
\text { (1993) }\end{array}$ \\
\hline $\mathrm{Rm} 0540$ & Rm1021 exoY, Nod $^{+}$, Inf $^{-}, \mathrm{Fix}^{-}$ & Müller et al. $(1988,1993)$ \\
\hline Rm0540 (PXLGD) & $\mathrm{Rm} 0540, \mathrm{Lac}^{+}$ & A. Becker (Bielefeld) \\
\hline \multicolumn{3}{|l|}{ R. loti } \\
\hline NZP2037 & Wild-type & Pankhurst et al. (1979) \\
\hline
\end{tabular}


A. tumefaciens-mediated transformation and regeneration of M. sativa ssp. varia A2 plants with pPR89 was previously described by Bauer et al. (1996).

L. corniculatus cv. Rodeo transformation was carried out as described by Szabados et al. (1990) using seedlings that were inoculated at wounded hypocotyls with A. rhizogenes strain A4Tc24 (Petit et al. 1983) harboring pPR89. Fifteen independent hairy roots that developed from the hypocotyl were excised and transferred to half strength $\mathrm{SH}$ medium supplemented with $1 \%$ saccharose, $25 \mathrm{mg}$ of kanamycin per liter and $100 \mathrm{mg}$ of cefotaxime per liter (Roussel UCLAF, France) and propagated on fresh medium every 3 weeks. Shoots spontaneously regenerated from seven of the hairy root clones and were placed onto half strength SH medium to develop into full plants. Rooted plants were transferred into vermiculite and cultivated in the greenhouse. Plants were checked by genomic DNA hybridization blot for the presence of $n p t I I$ and gusA sequences (data not shown). Five of these regenerated plants expressed the gusA fusion during nodule development. To avoid perturbation and retardation of nodule development by the rol oncogenes present in these plants, one transgenic plant was brought to flowering and crossed to pollen from an untransformed plant. Among 10 plants of the progeny, two plants were found whose genomic DNA hybridized to gusA and nptII sequences but not to $A$. rhizogenes $\mathrm{T}_{\mathrm{L}}$-T-DNA sequences (data not shown). Both plants expressed the gusA fusion in the same way after inoculation with $R$. loti.

\section{Rhizobium strains.}

Rhizobium strains used are listed in Table 1. The plasmid pXLGD4 containing a lac Z fusion under control of a constitutive promoter ( $\delta$-ALA::lacZ) (Leong et al. 1985) was introduced by triparental conjugation (Ditta et al. 1977) into strain Rm8368.

\section{Growth conditions and plant treatments.}

To obtain homogenous material of the tetraploid transgenic Medicago and Lotus plants, all treatments were performed on rooted cuttings. After rooting in sterile water, greenhouse cuttings were transferred to an aeroponic system, containing during the first 10 days a nutritive solution, then for about 10 days a medium with reduced combined nitrogen composition as described by Allison et al. (1993). Plants were then treated in the following ways: For nodulation assays $10 \mathrm{ml}$ of overnight $R$. meliloti or $R$. loti cultures (OD approximately 0.4 ) resuspended in plant medium were added into the aeroponic growth chambers. For production of spontaneous nodules plants were continuously grown in the aeroponic system under nitrogen-limiting conditions altogether for 3 weeks. For treatment with auxins plants were transferred into closed jars, containing vermiculite previously soaked in Gibson medium devoid of combined nitrogen and supplemented with $10 \mu \mathrm{M}$ auxins (2,4D, NAA, IAA, purchased from Sigma) or crude extracts of EPS and KPS (Petrovics et al. 1993), kindly provided by G. Petrovics and B. Reuhs, respectively.

\section{Reverse transcription-PCR and DNA blot hybridization.}

Total RNA isolation, semi-quantitative multiple transcript reverse transcription-PCR, gel electrophoresis, and DNA transfer blot were performed according to Bauer et al. (1994) using for PCR reactions Taq polymerase and buffer from Appligene. MsEnod $12 B$ and $M s c 27$ probes were prepared by
PCR using the primers described in Bauer et al. (1994) in the presence of $2 \mathrm{mM}$ Dig-labeled dUTP (Boehringer). Hybridization procedures and detection with Lumigen-PPD were performed according to instructions by Boehringer for the use of the nonradioactive digoxigenin-labeling and detection system with modifications described in Dessaux et al. (1995).

\section{Histochemical localization of GUS and $\beta$-Gal activity, mi- croscopic analysis, and semithin sectioning of GUS stained material.}

Prefixation and GUS stainings were performed according to Pichon et al. (1994), by using for the GUS staining a $0.1 \mathrm{M}$ sodium phosphate buffer, $\mathrm{pH} 7.0$, supplemented with $0.5 \mathrm{mM}$ $\mathrm{X}$-D-glcA (5-bromo-4-chloro-3-indolyl- $\beta$-D-glucuronic acid cyclohexylammonium salt, Biosynth AG, Switzerland), $5 \mathrm{mM}$ EDTA, $0.5 \mathrm{mM}$ potassium ferricyanide, $0.5 \mathrm{mM}$ potassium ferrocyanide and $0,1 \%$ Triton-X 100 . The samples were incubated with GUS staining buffer under vacuum for 2 min and then placed at $37^{\circ} \mathrm{C}$. Growing alfalfa nodules were incubated with the GUS substrates for $30 \mathrm{~min}$ to $2 \mathrm{~h}$, alfalfa empty nodules, Lotus nodules and root samples overnight. Under these conditions GUS staining was cell specific and most intense.

Sections of the samples of 80 to $200 \mu \mathrm{m}$ were generated using the Micro-Cut H1200 (Biorad) and stained with GUS substrates in the presence of $2 \mathrm{mM}$ potassium ferri- and ferrocyanide. Double staining was performed as described by Pichon et al. (1994) using X-D-gal (5-bromo-4-chloro-3-indolyl$\beta$-D-galactopyranoside) or magenta-D-gal (5-bromo-6-chloro-3indolyl- $\beta$-D-galactopyranoside) for detection of $\beta$-Gal activity. All material was cleared as described by Pichon et al. (1992).

For semithin sectioning, GUS-stained material was fixed and paraplast-embedded according to McKhann and Hirsch (1993) and sectioned with a micro-Biocut 2035 (Reichert and Jung) into $10-\mu \mathrm{m}$ slices. Deparaffined sections were occasionally counterstained with toluidine blue $(0,2 \%$ in water). Starch was stained using a lugol solution containing $1 \%$ iodine and $1 \%$ potassium iodide, and subsequently washed. A Polyvar Reichert and Jung microscope (Austria) and a Wild M420 binocular (Switzerland) were used for observations.

\section{Spectrocolorimetric analysis of GUS activity.}

Total protein extracts were prepared from nitrogen-frozen and homogenized plant material with a $50 \mathrm{mM}$ sodium phosphate extraction buffer, $\mathrm{pH} 7.0,10 \mathrm{mM}$ EDTA, $10 \mathrm{mM} \beta$ mercaptoethanol supplemented with $1 \%$ polyclar AT. To 20to $30-\mu 1$ protein extract (between 15 and $30 \mu \mathrm{g}$ protein) were added $150-\mu l$ extraction buffer (devoid of polyclar AT) supplemented with $1 \mathrm{mM}$ pnp-D-gluc (4-nitrophenyl- $\beta$-Dglucuronide, Biosynth AG, Switzerland). For determining GUS activity the $\mathrm{OD}_{405}$ were measured initially and after further time points using the automatic EAR 400ATC OD reader (Roucaire). GUS reactions were repeated four times per protein extract. Mean GUS activities and standard deviations were calculated out of four measurements for each protein extract (in relative OD changes/g total protein mass/min).

\section{ACKNOWLEDGMENTS}

We are grateful to M. Crespi for discussions and C. Staehelin for critically reading the manuscript. A doctoral fellowship from the Gottlieb Daimler and Carl Benz Foundation to P. B. is greatly acknowledged. EPS and KPS were kindly provided by G. Petrovics (Szeged) and 
B. Reuhs (Athens, GA). An inoculum of G. mosseae was given by C. Staehelin and Z.P. Xie (Basel). Rm41 mutant derivatives were provided by P. Putnoky (Szeged), Rm8368 by A. Ichige (Cambridge, MA) and Rm0540 (pXLDG) by A. Becker (Bielefeld).

\section{LITERATURE CITED}

Allen, E. K., Allen, O. N. and Newman, A. S. 1953. Pseudonodulation of leguminous plants induced by 2-bromo-3,5-dichlorobenzoic acid. Am. J. Bot. 46:429-435.

Allison, L. A., Kiss, G. B., Bauer, P., Poiret, M., Pierre, M., Savouré, A., Kondorosi, E., and Kondorosi, A. 1993. Identification of two alfalfa nodulin genes with homology to members of the pea Enod12 gene family. Plant Mol. Biol. 21:375-380.

Bauer, P., Crespi, M. D., Szécsi, J., Allison, L. A., Schultze, M., Ratet, P., Kondorosi, E., and Kondorosi, A. 1994. Alfalfa Enod12 genes are differentially regulated during nodule development and Rhizobium invasion. Plant Physiol. 105:585-592.

Bauer, P., Ratet, P., Crespi, M. D., Schultze, M., and Kondorosi, A. 1996. Nod factors and cytokinins induce similar patterns of cortical cell division, amyloplast deposition and MsEnod12A expression paterns in alfalfa roots. Plant J. 10:91-105.

Cooper, J. B. and Long, S. R. 1994. Morphogenetic rescue of Rhizobium meliloti nodulation mutants by trans-zeatin secretion. Plant Cell 6:215-225

Crespi, M. D., Jurkevitch, E., Poiret, M., d'Aubenton-Carafa, Y., Petrovics, G., Kondorosi, E., and Kondorosi, A. 1994. enod40, a gene expressed during nodule organogenesis, codes for a non-translatable RNA involved in plant growth. EMBO J. 13:5099-5112.

Csanadi, G., Szécsi, J., Kalo, P., Kiss, P., Endre, G., Kondorosi, A., Kondorosi, E., and Kiss, G. B. 1994. Enod12, an early nodulin gene is not required for nodule formation and efficient nitrogen fixation in alfalfa. Plant Cell 6:201-213.

Dessaux, Y., Elasri, M., Glickmann, E., Oger, P., and VaudequinDransart, V. 1995. The use of digoxigenin-labeled probes to detect DNA sequences specific for plant pathogenic bacteria. Cell. Mol. Biol. 41:933-943.

Ditta, G., Stanfield, S., Corbin, D., and Helinski, D. R. 1977. Broad host-range DNA cloning systems for Gram-negative bacteria: Construction of a gene bank of Rhizobium meliloti. Proc. Natl. Acad. Sci. USA 77:7347-7351.

Ferreira, P. C. G., Hemerly, A. S., de Almeida-Engler, J., van Montagu, M., Engler, G., and Inzé, D. 1994. Developmental expression of the Arabidopsis cyclin gene cyclAt. Plant Cell 6:1763-1774.

Forrai, Y., Vincze, E., Banfalvi, Z., Kiss, G. B., Rhandhawa, G. S., and Kondorosi, A. 1983. Localization of symbiotic mutations in Rhizobium meliloti. J. Bacteriol. 153:635-643.

Franssen, H. J., Vijn, I., Yang, W. C., and Bisseling, T. 1992. Developmental aspects of the Rhizobium-legume symbiosis. Plant Mol. Biol. 19:89-107.

Glazebrook, J., Ichige, A., and Walker, G. C. 1993. A Rhizobium meliloti homolog of the Escherichia coli peptide-antibiotic transport protein SbmA is essential for bacteroid development. Genes Dev. 7:1485-1497.

Govers, F., Harmsen, H., Heidstra, R., Michielsen, P., Prins, M., and van Kammen, A. 1991. Characterization of the pea ENOD12B gene and expression analyses of the two ENOD12 genes in nodule, stem and flower tissue. Mol. Gen. Genet. 228:160-166.

Hemerly, A. S., Ferreira, P., de Almeida-Engler, J., van Montagu, M., Engler, G. and Inzé, D. 1992. cdc2a expression in Arabidopsis is linked with competence for cell division. Plant Cell 5:1711-1723.

Hirsch, A. M. 1992. Developmental biology of legume nodulation. New Phytol. 122:211-237.

Hirsch, A. M., Fang, Y., McKhann, H. I., Wycoff, K. L., Niner, B., Asad, S., Asmann, P. T., and Jacobs, M. 1994. Nodule development, early nodulins, and plant growth regulators. Pages 116-121 in: Proceedings of the 1st European Nitrogen Fixation Conference., Kiss G. B. and Endre G., eds. Officina Press, Szeged.

Hirsch, A. M., McKhann, H. I., and Löbler, M. 1992. Bacterial-induced changes in plant form and function. Int. J. Plant Sci. 153:S171-S181.

Horvath, B., Heidstra, R., Lados, M., Moerman, M., Spaink, H. P., Prome, J. C., van Kammen, A., and Bisseling, T. 1993. Lipooligosaccharides of Rhizobium induce infection-related early nodulin gene expression in pea root hairs. Plant J. 4:727-733.
Journet, E. P., Pichon, M., Dedieu, A., De Billy, F., Truchet, G., and Barker, D. G. 1994. Rhizobium meliloti Nod factors elicit cell-specific transcription of the Enod12 gene in transgenic alfalfa. Plant J. 6:241249.

Kondorosi, E., Banfalvi, Z., and Kondorosi, A. 1984. Physical and genetic analysis of a symbiotic region of Rhizobium meliloti: Identification of nodulation genes. Mol. Gen. Genet. 193:445-452.

Leigh, J. A., and Walker, G. C. 1994. Exopolysaccharides of Rhizobium: Synthesis, regulation and symbiotic function. Trends Genet. Sci. 10:63-67.

Leong, S. A., Williams, P. H., and Ditta, G. S. 1985. Analysis of the 5 regulatory region of the gene for $\delta$-aminolevulinic acid synthetase of Rhizobium meliloti. Nucleic Acids Res. 13:5965-5976.

Müller, P., Hynes, M. F., Kapp, D., Niehaus, K., and Pühler, A. 1988. Two classes of Rhizobium meliloti infection mutants differ in exopolysaccharide production and in coinoculation properties with nodulation mutants. Mol. Gen. Genet. 211:17-26.

Müller, P., Keller, M., Weng, W. M., Quandt, J., Arnold, W., and Pühler, A. 1993. Genetic analysis of the Rhizobium meliloti exoYFQ operon: exoY is homologous to sugar transferases and exo $Q$ represents a transmembrane protein. Mol. Plant-Microbe Interact. 6:55-65.

Nap, J.-P., and Bisseling, T. 1990. Nodulin function and nodulin gene regulation in root nodule development. Pages 181-230 in: The Molecular Biology of Symbiotic Nitrogen Fixation. P. M. Gresshoff, ed. CRC Press, Inc., Boca Raton, FL.

Niehaus, K., Kapp, D., and Pühler, A. 1993. Plant defence and delayed infection of alfalfa pseudonodules induced by an exopolysaccharide (EPSI)-deficient Rhizobium meliloti mutant. Planta 190:415-425.

Petit, A., David, C., Dahl, G. A., Ellis, J. G., Guyon, P., Casse-Delbart, F., and Tempé, J. 1983. Further extension of the opine concept: Plasmids in Agrobacterium rhizogenes cooperate for opine degradation. Mol. Gen. Genet. 190:204-214.

Petrovics, G., Putnoky, P., Reuhs, B., Kim, J., Thorp, T. A., Noel, K. D., Carlson, R. W., and Kondorosi, A. 1993. The presence of a novel type of surface polysaccharide in Rhizobium meliloti requires a new fatty acid synthase-like gene cluster involved in symbiotic nodule development. Mol. Microbiol. 8:1083-1094.

Pichon, M., Journet, E.-P., De Billy, F., Dedieu, A., Huguet, T., Truchet, G., and Barker, D. G. 1994. Enod12 gene expression as a molecular marker for comparing Rhizobium-dependent and -independent nodulation in alfalfa. Mol. Plant-Microbe Interact. 7:740-747.

Pichon, M., Journet, E.-P., Dedieu, A., De Billy, F., Truchet, G., and Barker, D. G. 1992. Rhizobium meliloti elicits transient expression of the early nodulin gene Enod12 in the differentiating root epidermis of transgenic alfalfa. Plant Cell 4:1199-1211.

Putnoky, P., Petrovics, G., Kereszt, A., Grosskopf, E., Ha, D. T. C., Banfalvi, Z., and Kondorosi, A. 1990. Rhizobium meliloti lipopolysaccharide and exopolysaccharide can have the same function in the plantbacterium interaction. J. Bacteriol. 172:5450-5458.

Scheres, B., van Engelen, F., van den Knaap, E., van de Wiel, C., van Kammen, A., and Bisseling, T. 1990. Sequential induction of nodulin gene expression in the developing pea nodule. Plant Cell 2:687-700.

Scheres, B., McKhann, H. I., Zalensky, A., Löbler, M., Bisseling, T., and Hirsch, A. M. 1992. The PsEnod12 gene is expressed at two different sites in Afghanistan pea pseudonodules induced by auxin transport inhibitors. Plant Physiol. 100:1649-1655.

Scheres, B., van de Wiel, C., Zalensky, A., Horvath, B., Spaink, H., van Eck, H., Zwartkruis, F., Wolters, A.-M., Gloudemans, T., van Kammen, A., and Bisseling, T. 1990. The Enod12 gene product is involved in the infection process during the pea-Rhizobium interaction. Cell 60:281-294.

Schultze, M., Kondorosi, E., Ratet, P., Buiré, M., and Kondorosi, A. 1994. Cell and molecular biology of Rhizobium-plant interactions. Int. Rev. Cytol. 156:1-75.

Taté, R., Patriarca, E. J., Riccio, A., Defez, R., and Iaccarino, M. 1994. Development of Phaseolus vulgaris root nodules. Mol. Plant-Microbe Interact. 7:582-589.

Truchet, G., Barker, D. G., Camut, S., De Billy, F., Vasse, J., and Huguet, T. 1989. Alfalfa nodulation in the absence of Rhizobium. Mol. Gen. Genet. 219:65-68.

van de Wiel, C., Norris, J. H., Bochenek, B., Dickstein, R., Bisseling, T., and Hirsch, A. M. 1990. Nodulin gene expression and ENOD2 localization in effective, nitrogen-fixing and ineffective, bacteria-free nodules of alfalfa. Plant Cell 2:1009-1017. 
Vijn, I., Martinez-Abarca, F., Yang, W. C., Neves, L.d., van Brussel, A., van Kammen, A., and Bisseling, T. 1995a. Early nodulin gene expression during Nod factor-induced processes in Vicia sativa. Plant J. 8:111119.
Vijn, I., Yang, W. C., Pallisgard, N., Ostergaard-Jensen, E, van Kammen, A., and Bisseling, T. 1995b. VsEnod5, VsEnod12 and VsEnod40 expression during Rhizobium-induced nodule formation on Vicia sativa roots. Plant Mol. Biol. 28:1111-1119. 